\title{
Analysis of current approaches to the treatment and quality of life improvement in patients with gastroesophageal reflux disease in case of its combination with the syndrome of undifferentiated connective tissue dysplasia.
}

\author{
Iryna B. Romash
}

Ivano-Frankivsk National Medical University, Ukraine.

\begin{abstract}
When the structure of the connective tissue is disturbed, the probability of developing pathology of the internal organs increases. The gastrointestinal tract is one of the systems that is most often involved in the pathological process in the case of such disorders. Due to its mesenchymal origin, the esophagus is one of the first to suffer.

Normalization of mineral metabolism, correction of immunological and bioenergetic status are the main tasks in the treatment of such patients. Therapy with magnesium drugs, vitamins, anabolic drugs, $\beta$-blockers, aldosterone antagonists, and amino acid drugs should also be used for this purpose. Patients in this group should also take drugs that contain vitamin D3.
\end{abstract}

\section{Keywords}

quality of life, undifferentiated connective tissue dysplasia, gastroesophageal reflux disease

Address for correspondence:

Romash Iryna Bohdanivna, MD, Ph.D., assistant of professor Department propaedeutics of internal medicine, Ivano-Frankivsk National Medical University. Pylyp Orlyk str., 5/7. 76010 Ivano-Frankivsk, Ukraine.

e-mail: iromash@ukr.net; iromash@ifnmu.edu.ua

Submitted for publication: 03 March 2021

This work is licensed under a Creative Commons AttributionNonCommercial 4.0 International License (CC BY-NC 4.0).

\section{(c) (i) (9)}

(C)Copyright: Romash, 2021

Licensee NDSAN (MFC- Coordinator of the NDSAN), Italy doi: https://doi.org/10.32437/mhgcj.v4i2.120
Revised: 07August 2021

Accepted for publication: 07 September 2021

\section{Introduction}

Undifferentiated connective tissue dysplasia (UCTD) refers to unclassified systemic autoimmune pathologies that have common clinical and serological manifestations with certain connective tissue diseases (CTD) but do not meet any of the criteria for their classification (Mosca, Tani, Vagnani et.al., 2014).

The natural evolution of UCTD has not yet been definitively established, and according to the results of eleven years of observation of such patients, about $62 \%$ of them continue to suffer from it, $24 \%$ have reverse development, and $14 \%$ developed specific connective tissue 
disease (CTD) (García-González, RodríguezLozano, Bustabad, Ferraz-Amaro, 2017).

Patients with UCTD are more susceptible to adjuvant factors, including proximity to factories, plants, wearing metal implants, vaccination. One of the systems most often involved in the pathological process in UCTD is the gastrointestinal tract, and among its organs in one of the first places - lesions of the esophagus, which is probably due to its mesenchymal origin (Bodolay et al., 2003).

\section{Design/Methodology/Approach}

The aim of the study was to summarize the existing knowledge about modern approaches to treatment in patients with gastroesophageal reflux disease on the background of the syndrome of undifferentiated connective tissue dysplasia while proposing an action plan to improve their quality of life.

Based on the obtained data, the authors aim to raise the awareness of interested health professionals and create a basis for further research.

\section{Results and discussion}

Treatment of gastroesophageal reflux disease (GERD) involves focusing on those pathological conditions that contribute to the strengthening of pathogenetic links of development and the appointment of antireflux therapy.

Drugs of choice for GERD pharmacotherapy are antisecretory agents and primarily proton pump inhibitors (PPIs) (Sawada, 2020; Sharma, Yadlapati, 2020; Surdea-Blaga, 2016). Two ways can also be used to increase the effectiveness of treatment and the rapid elimination of symptoms, including the combination of PPIs with alginates, antacids, or prokinetics or increasing the dose of the drug (Januszewicz, 2019). The expediency of the use of pharmaceuticals aimed at protecting the mucous membrane of the esophagus is due to the pathogenesis of GERD, namely - cellular and molecular mechanisms of inflammatory changes in the mucous membrane of the esophagus. Healthy esophageal epithelium provides an effective barrier to permeability between reflux and esophageal nociceptors, as its cells normally have acid buffering and acid transport properties (Müller, 2019).

The phenomenon of "acid pocket" has been in the center of attention of aciddependent pathology of the esophagus for more than a decade. Although its appearance postprandial is a physiological phenomenon, in patients with GERD it is usually larger and more proximal, so it may increase the tendency to acid reflux, especially if the lower esophageal sphincter (LES) is caused by a lack of its connective tissue components. It has been scientifically confirmed that "acid pocket" as a dynamic phenomenon is a bad target only for acid-blocking agents (Chernobrovyj, Melashchenko, Chernobrova, Ksenchyn, 2017). In such cases, it will be more appropriate to prescribe a complex of acidsuppressive therapy with an alginate-antacid combination, because according to international treatment protocols, it may be more useful than acid-suppressive therapy alone (WGO, 2015).

The Romanian Society of Neurogastroenterology conducted a systematic scientifically based analysis, according to which it concluded the benefits of adding to the PPI drugs aimed at protecting the esophageal mucosa. In particular, they note that the alginate-antacid combination is superior to both placebo and antacids for the treatment of mild reflux symptoms, and has proven to be an additional agent to PPIs for the treatment of persistent symptoms. Alginate-antacid complex, in addition, to quickly eliminating symptoms, gave almost no side effects, improved quality of life. American researchers Leiman, DA et al. (2017) in the systematized literature review data also draw attention to the higher efficacy of alginates for the treatment of symptomatic GERD, as opposed to placebo and antacids. "Gaviscon double action! has a unique mechanism of action, forming a gel-like barrier on the surface of the gastric contents, which prevents aggressive gastric contents from entering the esophagus.

According to scientific data, it was especially effective in the fight against postprandial "acid pockets". Even in cases of gastric contents entering the esophagus, alginates are ahead of it, protecting the walls of the esophagus from the negative effects of gastric contents. Studies by Muller $M$ et al. (2019), which prove its effectiveness and safety and emphasizes the role of this alginate 
complex in combating the symptom of "night break", as a result of which the quality of sleep in patients improves. This study is also supported by a randomized clinical trial of Coyle C et al. (2017).

Concerning UCTD, from a clinical point of view, such a group of patients needs a differentiated approach to treatment and prevention technologies. For treating patients with such comorbid pathology necessary to take into account the pathogenetic mechanisms of its development and actively involve clinicians of various profiles. There are currently no international UCTD treatment protocols that prescribe specific treatments. An important element of treatment is the proper nutrition of such patients with foods enriched with substances that are actively involved in connective tissue metabolism.

Normalization of mineral metabolism, correction of immunological and bioenergetic status are the main tasks in the treatment of such patients (Butkova, 2018; Mishchuk, 2019). Therapy with magnesium drugs, vitamins, anabolic drugs, $\beta$-blockers, aldosterone antagonists, and amino acid drugs used for this purpose (Solieiyko, 2014; Antunes et al., 2019). Also, patients in this group should use drugs containing vitamin D3, the lack of which leads to a deficiency of calcium, zinc, and disorders of calcium-phosphorus metabolism. And all this leads to disorders of connective tissue metabolism (Omelchenko, Mukvich, Lavrenchuk, 2017; Romash, 2019).

Micro- and macroelements, vitamins, as cofactors of matrix metalloproteinases, play an important role in the synthesis of the main structural proteins of connective tissue. In particular, $\mathrm{Mg} 2+$ affects the activity of enzymes involved in collagen formation, giving the connective tissue matrix elasticity and resilience.

Pyridoxine is also important for metabolic support of connective tissue function and stimulation of collagen formation (Solieiyko, $2014 ; 2018)$. Its deficiency leads to peeling of the skin, dandruff, eczema. Having the ability to affect the level of endogenous amino acids, it helps to normalize keratin, the main protein of the connective tissue of the skin, nails, hair. With magnesium and pyridoxine deficiency, connective tissue protein synthesis slows down (Omelchenko, Mukvich, Lavrenchuk, 2017).

In addition, vitamin B6 is a universal carrier of $\mathrm{Mg} 2+$ in the middle of the cell, providing its homeostasis. After all, Mg2+ deficiency increases the activity of matrix metalloproteinases (MMPs) which causes aggressive degradation of collagen fibers with subsequent loss of connective tissue strength.

Experimental work has begun in recent years to show that magnesium deficiency can also affect the development of GERD. Smooth muscle contraction is known to regulate vascular tone. And the balance of $\mathrm{Ca} 2+$ and $\mathrm{Mg} 2+$ ions maintain adequate blood flow and trophic of the submucosal layer of the esophagus, provides post-epithelial protection of the mucous membrane (Akyüz, Mutluay Soyer, 2017). Therefore, the imbalance and/or deficiency of these ions can disrupt the processes of neuromuscular transmission and muscle contraction, which in turn manifests itself in the form of GER and duodenogastric reflux (DGR). Decreased magnesium concentration in the body contributes to a more severe course of GERD and reduced quality of life (ludici et.al., 2017). At the same time, the dynamics of $\mathrm{Mg} 2+, \mathrm{Ca} 2+$, and MMPs activity under the influence of drugs containing magnesium and calcium were not studied in patients with GERD on the background of UCTD.

\section{Conclusions}

Therefore, there are currently no clear recommendations for the treatment of GERD on the background of UCTD. Recommendations for the correction of metabolic disorders in GERD on the background of UCTD are few and insufficiently substantiated. The frequency of such comorbid pathology indicates the need to find new ways of early diagnosis and correction of this process.

\section{Conflict of interest}

The author declares that she has no conflict of interests.

\section{References}

Akyüz, F., Mutluay Soyer, Ö. (2017). Which diseases are risk factors for developing gastroesophageal reflux disease? Turk J Gastroenterol. (1):44-47.

Antunes, M., Scirè, C.A., Talarico, R. et al. (2019). Undifferentiated connective tissue disease: state of the art on clinical practice guidelines. RMD Open.;4:e000786. 
Bodolay, E., Csiki, Z., Szekanecz, Z., Ben, T., Kiss, E., Zeher, M., Szücs, G., Dankó, K., Szegedi, G. (2003). Five-year follow-up of 665 Hungarian patients with undifferentiated connective tissue disease (UCTD). Clin Exp Rheumatol. 21 (3):313-20.

Butkova, O.I., Zhabchenko, I.A., Oleshko, V.A. (2018). Features of the microelements exchange and connective tissue state in the first-pregnant women with a disruption of cervical ripening in the second half of pregnancy. Medical aspects of women's health. 3(116):11-15.

Chernobrovyj, V.M., Melashchenko, S.G., Chernobrova, O.I., Ksenchyn, O. O. (2017). Gastroesophageal reflux disease: the main accents of modern differentiated and controlled pharmacotherapy. Modern gastroenterology. 4(96):33-42.

Coyle, C., Crawford, G., Wilkinson, J., Thomas, S.J., Bytzer, P. (2017). Randomised clinical trial: addition of alginate-antacid (Gaviscon Double Action) to proton pump inhibitor therapy in patients with breakthrough symptoms. Aliment Pharmacol Ther.45(12):1524-33.

García-González, M., Rodríguez-Lozano, B., Bustabad, S., Ferraz-Amaro, I. (2017). Undifferentiated connective tissue disease: predictors of evolution into definite disease. Clin Exp Rheumatol. 35(5):73945.https://mhgcj.org/index.php/MHGCJ/ar ticle/view/70. [176].

Iudici, M., Irace, R., Riccardi, A., Cuomo, G., Vettori, S., Valentini, G. (2017). Longitudinal analysis of quality of life in patients with undifferentiated connective tissue diseases. Patient Relat Outcome Meas. 8:7-13.

Januszewicz, W., Hartley, J., Waldock, W., Roberts, G., Alias, B., Hobson, A., Wernisch, L., di Pietro, M. (2019). Endoscopic measurement of gastric $\mathrm{pH}$ associates with persistent acid reflux in patients treated with proton-pump inhibitors for gastroesophageal reflux disease. United European Gastroenterol J. Dec $1 ; 7(10): 1389-98$

Leiman, D.A., Kochar, B., Posner, S., Fan, C., Patel, A., Shaheen, O.A. et al. (2018). A diagnosis of eosinophilic esophagitis is associated with increased life insurance premiums. Diseases of the Esophagus. 31:15.

Mishchuk, V. G., Romash, I. B. (2019). The specific features of syndrome of undifferentiated connective tissue dysplasia and collagen exchange indices in case of its combination with the gastroesophageal reflux disease. 3(107):6874.

Mosca, M., Tani, C., Vagnani, S., Carli, L., Bombardieri, S. (2014). The diagnosis and classification of undifferentiated connective tissue diseases. J. Autoimmun. 48-49:50-2.

Müller, M., Labenz, G., Borkenstein, D-P., Labenz J. (2019). Alginat bei Bedarf als Addon bei unzureichendem Effekt von Protonenpumpen-Hemmern bei Patienten mit gastroösophagealer Reflux-Krankheit. DMW - Deutsche Medizinische Wochenschrift 144:e30-5.

Omelchenko, L.I., Mukvich, O.M., Lavrenchuk, O.V. (2017). On vitamin D-dependent regulation of local mechanisms of nonspecific defense in children with connective tissue dysplasia. CHILD'S HEALTH， 12(8), 890-894. https://doi.org/10.22141/22240551.12 .8 .2017 .119244

Romash, IB. (2019). Peculiarities of the course and treatment of gastroesophageal reflux disease in patients with syndrome of undifferentiated connective tissue dysplasia. (Systematic literature review). MHGCJ [Internet]. Dec. 27 [cited 2021 Feb. 22];:76-8.

Romash, I. B., Mishchuk, V. G., Ersteniuk G.M. (2019). Level of different micro and macroelements and activity of matrix metalloproteinase 9 in patients with gastroesophageal reflux disease that developed against the background of undifferentiated connective tissue dysplasia 4:5-11.

Sawada, A., Sifrim, D. (2020). Reply. Clinical Gastroenterology and Hepatology. 1

Sharma, P., Yadlapati, R. (2020). Pathophysiology and treatment options for gastroesophageal reflux disease: looking beyond acid. Ann N Y Acad Sci.

Solieiko, O.V., Rykalo, N.A., Osypenko, I.P., Soleiko, L.P. (2014). Syndrome of undifferentiated connective tissue dysplasia: from the concept of pathogenesis to treatment strategy. Study guide for students. higher honey. textbook institutions of III-IV levels of accreditation. Vinnytsia: Nova knyha; $168 \mathrm{~s}$.

Surdea-Blaga, T., Băncilă, I., Dobru, D., Drug, V., Frățilă, O., Goldiș, A. et.al. (2016). Mucosal Protective Compounds in the 
Treatment of Gastroesophageal Reflux Disease. A Position Paper Based on Evidence of the Romanian Society of
Neurogastroenterology. J Gastrointestin Liver Dis. 25 (4):537-46.. 